\title{
Characterization of Residual Particulates from Biomass Entrained Flow Gasification
}

Qin, Ke; Lin, Weigang; Fæster, Søren; Jensen, Peter Arendt; Wu, Hao; Jensen, Anker Degn

Published in:

Energy \& Fuels

Link to article, DOI:

$10.1021 /$ ef301432q

Publication date:

2013

Document Version

Publisher's PDF, also known as Version of record

Link back to DTU Orbit

Citation (APA):

Qin, K., Lin, W., Fæster, S., Jensen, P. A., Wu, H., \& Jensen, A. D. (2013). Characterization of Residual Particulates from Biomass Entrained Flow Gasification. Energy \& Fuels, 27(1), 262-270. https://doi.org/10.1021/ef301432q

\section{General rights}

Copyright and moral rights for the publications made accessible in the public portal are retained by the authors and/or other copyright owners and it is a condition of accessing publications that users recognise and abide by the legal requirements associated with these rights.

- Users may download and print one copy of any publication from the public portal for the purpose of private study or research.

- You may not further distribute the material or use it for any profit-making activity or commercial gain

- You may freely distribute the URL identifying the publication in the public portal 


\title{
Characterization of Residual Particulates from Biomass Entrained Flow Gasification
}

\author{
Ke Qin, ${ }^{\dagger}$ Weigang Lin, ${ }^{\dagger}$ Søren Fæster, ${ }^{\ddagger}$ Peter Arendt Jensen, ${ }^{\dagger}$ Hao Wu, ${ }^{\dagger}$ and Anker Degn Jensen ${ }^{* \dagger}$ \\ ${ }^{\dagger}$ Department of Chemical and Biochemical Engineering, Technical University of Denmark, 2800 Kgs. Lyngby, Denmark \\ ${ }^{*}$ Department of Wind Energy, Technical University of Denmark, 4000 Roskilde, Denmark
}

\section{Supporting Information}

\begin{abstract}
Biomass gasification experiments were carried out in a bench scale entrained flow reactor, and the produced solid particles were collected by a cyclone and a metal filter for subsequent characterization. During wood gasification, the major part of the solid material collected in the filter is soot. Scanning electron microscopy (SEM) images coupled with energy dispersive spectroscopy (EDS) show agglomerated nanosize spherical soot particles $(<100 \mathrm{~nm})$ that are very rich in carbon. In comparison to wood gasification, the soot content in the filter sample from straw gasification is quite low, while the contents of $\mathrm{KCl}$ and $\mathrm{K}_{2} \mathrm{SO}_{4}$ in the filter sample are high. SEM images of the straw filter samples show that with steam addition during gasification, where the soot yield is lower, the filter sample becomes richer in $\mathrm{KCl}$ and $\mathrm{K}_{2} \mathrm{SO}_{4}$ and appears as irregular crystals, and the typical particle size increases from below $100 \mathrm{~nm}$ to above $100 \mathrm{~nm}$. During gasification of dried lignin, the filter sample mainly consists of soot and nonvolatilizable inorganic matter. SEM images of the parent wood particles and the derived char samples show that they have similar structure, size, and shape but the derived char particle surface looks smoother indicating some degree of melting. The reactivity of the organic fraction of the samples was determined by thermogravimetry, and it was found that char was more reactive than soot with respect to both oxidation and $\mathrm{CO}_{2}$ gasification. The activation energy for the soot conversion is higher than for the char conversion. These results support the observation from gasification experiments that char is more easily converted than soot. Surprisingly, the soot produced at a higher temperature is more reactive than the soot produced at a lower temperature.
\end{abstract}

\section{INTRODUCTION}

Gasification of solid fuels, such as coal and biomass, is a way of producing synthesis gas that can be used to make a range of products such as hydrogen, methanol, dimethyl ether, and synthetic natural gas, as well as heat and power. ${ }^{1}$ Generally, the various gasifiers used can be grouped in three main classes: fixed bed, fluidized bed, and entrained flow. ${ }^{2}$ The majority of the coal gasification processes that have been developed after 1950 are based on entrained flow gasifiers, and the majority of commercial-sized IGCC plants also use entrained flow gasifiers. ${ }^{3}$ The main advantages of entrained flow gasification are fuel flexibility, ${ }^{4}$ large capacity, ${ }^{5,6}$ high carbon conversion, ${ }^{7,8}$ and high quality syngas. ${ }^{2,9}$ In many countries, biomass represents a domestic energy source that can ensure a secure supply of raw material to the energy system. In addition, the use of biomass as a fuel can reduce the $\mathrm{CO}_{2}$ emission. Owing to the high volatile content in biomass, a potential problem in biomass gasification is the large amount of tar formed that is an undesired byproduct. ${ }^{10-13}$ However, entrained flow gasification operates at high temperature, thus a tar-free gas can be obtained.

In entrained flow gasification, the fuel conversion includes pyrolysis, char and soot oxidation and gasification by $\mathrm{CO}_{2}$ and $\mathrm{H}_{2} \mathrm{O}$, and gas phase reactions. Among these, char and soot gasification are the conversion limiting steps because the heterogeneous reactions are slower than the initial pyrolysis and the gas phase reactions. ${ }^{14,15}$ In previous experiments of biomass (wood and straw) entrained flow gasification, we found a low yield of char $(<0.1 \mathrm{wt} \%)$ at $1000{ }^{\circ} \mathrm{C}$ while no char was left at higher reactor temperatures. On the other hand, soot was always observed in the syngas in the temperature range 1000$1400{ }^{\circ} \mathrm{C} .{ }^{16}$ Thus, in comparison to char gasification, soot gasification appears to be a slower process and hence determines the overall fuel conversion of the gasification process and influences the syngas quality. ${ }^{17}$ Therefore, knowledge on soot conversion is needed, but presently, little is known about the properties of soot particles emitted from biomass entrained flow gasification. ${ }^{16,18}$

The objective of the present work was to characterize the residual solid particles obtained from biomass entrained flow gasification and, particularly, to determine the reactivity of the soot and char particles. Simultaneous thermal analysis (STA) was employed to determine the sample composition and reactivity with respect to oxidation and $\mathrm{CO}_{2}$ gasification of the particles. Scanning electron microscopy (SEM) with energy dispersive X-ray spectrometry (EDS) was used to examine the size, morphology, and elemental composition of the solid particles.

\section{EXPERIMENTAL SECTION}

Fuels. Wood (beech sawdust) and straw (pulverized wheat straw pellet), which are typical forestry and agricultural wastes respectively, were used as biomass fuels. Lignin, a waste stream from bioethanol production, with very high moisture content $(69.2 \mathrm{wt} \%$, as-received

Received: September 1, 2012

Revised: November 1, 2012

Published: November 23, 2012 
basis), was also used as a fuel for comparison. After suction filtration, the lignin was dried at $105{ }^{\circ} \mathrm{C}$ for $24 \mathrm{~h}$. To attain a stable feeding during entrained flow gasification, the dried lignin was sieved to a desired particle size below $1 \mathrm{~mm}$. The particle size distributions of the three fuels, shown in Figure 1, were determined by sieve classification.

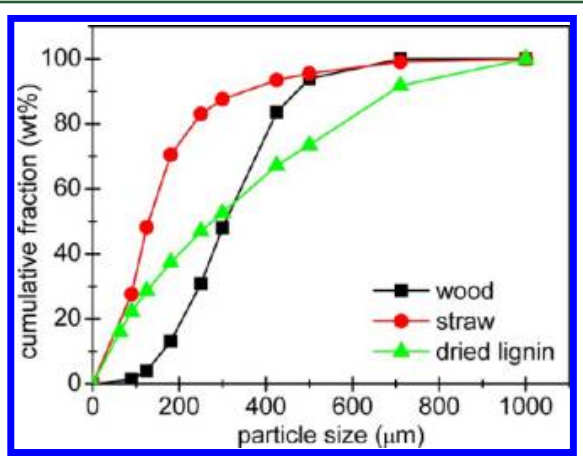

Figure 1. Particle size distributions of fuels.

The median diameters ( $\mathrm{d} 50)$ of wood, straw, and dried lignin were 310,130 , and $280 \mu \mathrm{m}$, respectively. Their proximate and ultimate analyses are listed in Table 1 . The compositions of wood and straw are

Table 1. Properties of Fuels

\begin{tabular}{|c|c|c|c|}
\hline properties & $\begin{array}{l}\text { wood (as- } \\
\text { received basis) }\end{array}$ & $\begin{array}{l}\text { straw (as- } \\
\text { received basis) }\end{array}$ & $\begin{array}{l}\text { dried lignin } \\
\text { (dry basis) }\end{array}$ \\
\hline moisture (wt \%) & 9.04 & 5.40 & 0.00 \\
\hline ash (wt \%) & 0.61 & 4.54 & 12.10 \\
\hline volatile (wt \%) & 76.70 & 72.27 & 61.20 \\
\hline $\begin{array}{l}\text { fixed carbon (wt \%) } \\
\text { (by diff.) }\end{array}$ & 13.65 & 17.79 & 26.70 \\
\hline $\begin{array}{l}\text { lower heating value } \\
(\mathrm{MJ} / \mathrm{kg})\end{array}$ & 16.44 & 16.35 & 21.42 \\
\hline $\mathrm{C}($ wt \%) & 45.05 & 43.42 & 57.80 \\
\hline H (wt \%) & 5.76 & 5.58 & 5.70 \\
\hline O (wt \%) (by diff.) & 39.41 & 40.60 & 23.60 \\
\hline N (wt \%) & 0.13 & 0.37 & 1.20 \\
\hline S (wt \%) & 0.01 & 0.09 & 0.14 \\
\hline $\mathrm{Si}($ wt \%) & & 1.23 & 4.18 \\
\hline K (wt \%) & & 0.76 & 0.13 \\
\hline $\mathrm{Cl}$ (wt \%) & & 0.25 & 0.02 \\
\hline $\mathrm{Ca}($ wt \%) & & 0.23 & 0.43 \\
\hline $\mathrm{Mg}($ wt \%) & & 0.06 & 0.02 \\
\hline P (wt \%) & & 0.03 & 0.06 \\
\hline $\mathrm{Na}($ wt \%) & & 0.01 & 0.28 \\
\hline $\mathrm{Al}$ (wt \%) & & 0.01 & 0.07 \\
\hline $\mathrm{Fe}(\mathrm{wt} \%)$ & & 0.01 & 0.30 \\
\hline
\end{tabular}

quite similar, with high volatile content and low fixed carbon content, but straw has higher ash content, and the ash is rich in potassium. Compared with wood and straw, the dried lignin has higher heating value and fixed carbon content, lower volatile content, and higher ash content. The ash of dried lignin is rich in silica.

Gasification Experiments in an Entrained Flow Reactor. The experimental setup used in the present work includes an entrained flow reactor and is described in detail in our previous studies. ${ }^{16}$ In the experiments, the reactor temperature was set at $1000-1400{ }^{\circ} \mathrm{C}$. The fuel was fed by a gravimetric screw feeder and was carried into a vertical electrically heated reaction tube (a length of $2 \mathrm{~m}$ with an inner diameter of $0.08 \mathrm{~m}$ ) through a water-cooled feeding probe together with the feeder gas. They were mixed with steam, preheater main gas, and purge gas at the inlet of the reaction tube. At the outlet of the reaction tube, the produced syngas was directed to a heat exchanger and then to a burner designed for flue gas treatment. The gas products (mainly $\mathrm{H}_{2}, \mathrm{CO}, \mathrm{CO}_{2}, \mathrm{CH}_{4}$, and $\mathrm{C}_{2} \mathrm{H}_{2}$ ) were continuously sampled after the heat exchanger and were cleaned and dried by a filter and a gas cooler. The composition of gas samples without dust and water was measured by a NDIR gas analyzer and a micro gas-chromatograph (Agilent 3000). When the measured gas composition reached a stable state, a certain amount of syngas was drawn to a solid sampling system through a bottom sampling probe according to the principle of isokinetic sampling. In the solid sampling system, the larger particles were collected by a cyclone, and the smaller particles passing the cyclone were captured by a metal filter. The designed cut size of the cyclone was $2.5 \mu \mathrm{m}$. The bottom sampling probe, cyclone, and filter were heated to $400{ }^{\circ} \mathrm{C}$ to avoid liquid condensation. The solid particles were sampled for $10 \mathrm{~min}$ during each experiment that lasted approximately $60 \mathrm{~min}$. After each experiment, when the solid sampling system was cooled to room temperature, the solid particles in the cyclone and metal filter were collected, weighed, and preserved for further analysis.

Property Analysis of Residual Solid Particles. The solid particles collected by the cyclone and metal filter during entrained flow gasification were analyzed by various analytical techniques. Simultaneous thermal analysis (STA) was employed to determine different fractions of the samples. In each analysis, $5 \mathrm{mg}$ samples were loaded in a platinum crucible and heated at $10{ }^{\circ} \mathrm{C} / \mathrm{min}$ to the final setting temperature in a thermogravimetric apparatus (Netzsch STA-449C). The applied temperature program and gas environment is shown in Figure 2. Based on the STA analysis, different fractions of the solid

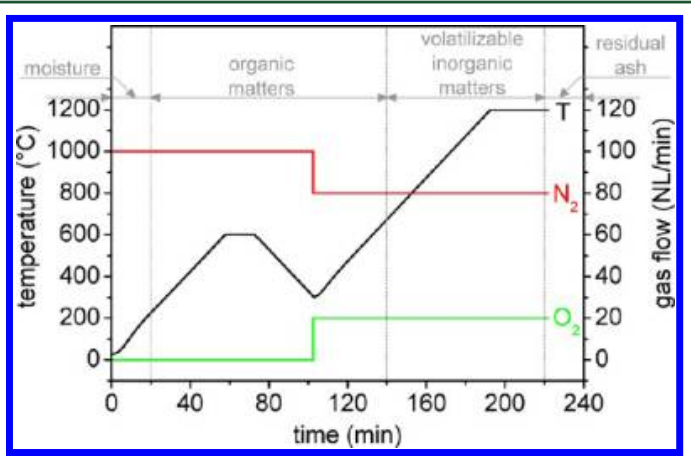

Figure 2. Temperature program and gas environment used for solid particles analysis.

particles, such as moisture, organic matters, volatilizable inorganic compounds, and residual ash, can be identified. For volatilizable inorganic compounds, different species, such as $\mathrm{KCl}$ and $\mathrm{K}_{2} \mathrm{SO}_{4}$, can be identified on the basis of their evaporating temperatures. The amount of organic matters in the filter sample is defined as soot. Scanning electron microscopy (SEM) with energy dispersive X-ray spectroscopy (EDS) was employed to obtain the size, morphology, and elemental distribution of the solid particles. The used apparatus was a Zeiss Supra 35 FEGSEM equipped with an X-ray analysis tool by Noran Instruments for filter sample analysis and a Quanta FEGSEM 200F for cyclone sample and parent fuel analysis.

Reaction Kinetics of Residual Solid Particles. The kinetics of the soot and char collected during wood entrained flow gasification were also derived by nonisothermal experiments in the thermogravimetric apparatus. In a measurement, approximate $1 \mathrm{mg}$ sample was loaded in an alumina crucible and heated at $5-10{ }^{\circ} \mathrm{C} / \mathrm{min}$ from room temperature to $800{ }^{\circ} \mathrm{C}$ during oxidation or to $1100{ }^{\circ} \mathrm{C}$ during gasification. The total gas flow was $100 \mathrm{~mL} / \mathrm{min}$. Three different $\mathrm{O}_{2}$ and $\mathrm{CO}_{2}$ concentrations were selected. The $\mathrm{O}_{2}$ concentrations in $\mathrm{N}_{2}$ were 10,15 , and $20 \mathrm{vol} \%$, and the $\mathrm{CO}_{2}$ concentrations in $\mathrm{N}_{2}$ were 10 , 50 , and 90 vol \%.

The sample conversion in the temperature range of oxidation or gasification was defined as

$$
\alpha=\frac{w_{\mathrm{i}}-w}{w_{\mathrm{i}}-w_{\mathrm{f}}}
$$


where $w$ was the sample weight at a certain temperature $T$ (or at a certain time $t), w_{\mathrm{i}}$ was the initial sample weight at the start of oxidation or gasification, and $w_{\mathrm{f}}$ was the final sample weight at the end of oxidation or gasification. The nonisothermal fuel conversion can be described by using an $n$th order reaction model with the rate constant given by the Arrhenius equation

$$
\begin{aligned}
& k=P_{\mathrm{g}}^{m} A_{0} \mathrm{e}^{(-E / R T)} \\
& \frac{\mathrm{d} \alpha}{\mathrm{d} T}=\frac{1}{\beta} k(1-\alpha)^{n}=\frac{1}{\beta} P_{\mathrm{g}}^{m} A_{0} \mathrm{e}^{(-E / R T)}(1-\alpha)^{n}
\end{aligned}
$$

where $T$ is the reaction temperature, $\beta$ is the heating rate, $P_{\mathrm{g}}$ is the $\mathrm{O}_{2}$ or $\mathrm{CO}_{2}$ partial pressure, $A_{0}$ is the pre-exponential factor, $E$ is the activation energy, $R$ is the ideal gas constant, and $m$ and $n$ are the reaction order with respect to gas phase and solid phase respectively. There was no change in the $\mathrm{O}_{2}$ or $\mathrm{CO}_{2}$ partial pressure during an experiment, so an apparent pre-exponential factor $A$ can be used as follows:

$$
A=P_{\mathrm{g}}^{m} A_{0}
$$

Thus, eq 3 can be expressed as

$$
\frac{\mathrm{d} \alpha}{\mathrm{d} T}=\frac{1}{\beta} A \mathrm{e}^{(-E / R T)}(1-\alpha)^{n}
$$

In the present study, a common integral method presented by Coats and Redfern ${ }^{19,20}$ was used to determine the kinetic parameters used in eq 5. Through integral transformation and mathematic approximation, eq 5 can be expressed in a linear form as ${ }^{19}$

$$
\ln \left[\frac{g(\alpha)}{T^{2}}\right]=-\frac{E}{R} \frac{1}{T}+\ln \left(\frac{A R}{\beta E}\right)
$$

here, if

$$
n=1, \quad g(\alpha)=-\ln (1-\alpha)
$$

otherwise,

$$
n \neq 1, \quad g(\alpha)=\left[(1-\alpha)^{1-n}-1\right] /(n-1)
$$

A plot of $\ln \left[g(\alpha) / T^{2}\right]$ versus $1 / T$ should give a straight line whose slope and intercept determine the values of the activation energy $E$ and the apparent pre-exponential factor $A$, respectively. Three different values, $1 / 2,2 / 3$, and 1 , of the reaction order $n$ were tested to determine which value provided the best fit.

In addition, eq 4 can be linearized by taking the natural log of both sides, shown as follows:

$$
\ln A=m \ln P_{\mathrm{g}}+\ln A_{0}
$$

For each sample, measurements at three concentrations of oxidant and gasification agent were performed. Thus, based on eq 9, a plot of $\ln A$ versus $\ln P_{\mathrm{g}}$ should give a straight line, from which the gas phase reaction order $m$ and pre-exponential factor $A_{0}$ are obtained from the slope and the intercept separately.

\section{RESULTS AND DISCUSSION}

Composition and Morphology of Residual Solid Particles. The weight loss curves (TG) of filter samples obtained from the entrained flow gasification of wood, straw, and dried lignin are shown in Figure 3, and the determined compositions of the three samples are listed in Table 2. In the three entrained flow gasification experiments, the operating parameters were fixed (reactor temperature $=1400{ }^{\circ} \mathrm{C}$; steam $/$ carbon molar ratio $=0.5$; excess air ratio $=0.3$; and oxygen concentration $=21 \%)$. During wood gasification, soot $(92.6 \mathrm{wt}$ $\%)$ is the major component in the filter sample. The temperature (about $1050{ }^{\circ} \mathrm{C}$ ) at which the inorganic matter starts to vaporize indicates that the major part of the

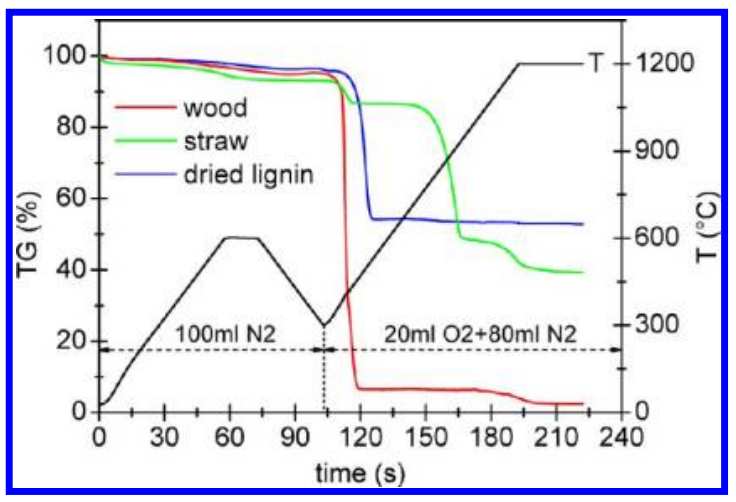

Figure 3. STA analysis of the filter samples obtained from biomass entrained flow gasification (operating parameters: $T=1400{ }^{\circ} \mathrm{C} ; \mathrm{H}_{2} \mathrm{O}$ / $\left.\mathrm{C}=0.5 ; \lambda=0.3 ; \mathrm{O}_{2}=21 \%\right)$.

volatilizable inorganic matter in the filter sample is $\mathrm{K}_{2} \mathrm{SO}_{4}$ $(4.2 \mathrm{wt} \%){ }^{21}$ During straw gasification, the soot content (11.1 wt \%) in the filter sample is low, while the volatilizable inorganic matter content (sum of $\mathrm{KCl}$ and $\mathrm{K}_{2} \mathrm{SO}_{4}$ is 47.4 wt \%) is high. According to the evaporating temperatures of about 700 and $1050{ }^{\circ} \mathrm{C},,^{21,22}$ the first volatilizable inorganic matter is $\mathrm{KCl}$ (38.2 wt \%) and the second is $\mathrm{K}_{2} \mathrm{SO}_{4}(9.2 \mathrm{wt} \%) . \mathrm{KCl}$ and $\mathrm{K}_{2} \mathrm{SO}_{4}$ were collected together with soot particles by the metal filter, because they appeared in the gas phase during gasification due to the high reactor temperature and then formed solid aerosols when the syngas was cooled. ${ }^{23-26}$ The filter sample obtained from dried lignin gasification mainly consists of soot (44.9 wt \%) and residual ash (52.9 wt \%). A small amount of volatilizable inorganic matter $(1.5 \mathrm{wt} \%)$ was mixed with the soot and ash. The ash of dried lignin mainly consists of silica and calcium, which are hard to volatilize.

Both gasification temperature and steam addition have an obvious influence on the soot yield. ${ }^{16,18}$ The compositions of filter samples obtained from wood entrained flow gasification at reactor temperatures of 1000 and $1400{ }^{\circ} \mathrm{C}$ with otherwise fixed operating parameters $($ steam $/$ carbon ratio $=0.5$; excess air ratio $=0.3$; and oxygen concentration $=21 \%$ ) are listed in Table 2, and the corresponding weight loss curves (TG) are shown in the Supporting Information. Soot (92.6-96.3 wt \%) was the major fraction in the two filter samples obtained at 1000 and $1400{ }^{\circ} \mathrm{C}$. Volatilizable inorganic matter, $\mathrm{K}_{2} \mathrm{SO}_{4}$, was present in the filter sample produced at $1400{ }^{\circ} \mathrm{C}$, while it was almost absent in the filter sample produced at $1000{ }^{\circ} \mathrm{C}$, probably because a smaller amount of $\mathrm{K}_{2} \mathrm{SO}_{4}$ aerosols were formed at the low temperature. The compositions of filter samples obtained from straw entrained flow gasification at reactor temperatures of 1000 and $1400{ }^{\circ} \mathrm{C}$ with otherwise fixed operating parameters $($ steam $/$ carbon ratio $=0.5$; excess air ratio $=0.3$; and oxygen concentration $=21 \%$ ) are listed in Table 2, and the corresponding weight loss curves (TG) are shown in the Supporting Information. The soot amount in the straw filter sample obtained at $1400{ }^{\circ} \mathrm{C}$ was lower than that obtained at $1000^{\circ} \mathrm{C}$. This is most likely because more soot was gasified at a higher temperature and possibly catalyzed by potassium species. The amount of volatilizable inorganic matter, $\mathrm{KCl}$ and $\mathrm{K}_{2} \mathrm{SO}_{4}$, in the filter sample obtained at $1400{ }^{\circ} \mathrm{C}$ was higher than that obtained at $1000^{\circ} \mathrm{C}$, probably due to the formation of $\mathrm{KCl}$ and $\mathrm{K}_{2} \mathrm{SO}_{4}$ aerosols at the high temperature.

The composition of filter samples obtained from straw entrained flow gasification at different steam/carbon molar ratios of 0.0, 0.5, and 1.0 with otherwise fixed operating 
Table 2. Composition of the Solid Samples Obtained from Biomass Entrained Flow Gasification

\begin{tabular}{|c|c|c|c|c|c|c|}
\hline \multirow[b]{2}{*}{ samples } & \multirow[b]{2}{*}{$\begin{array}{c}\text { moisture } \\
\text { (wt \%) }\end{array}$} & \multirow[b]{2}{*}{$\begin{array}{l}\text { organic matters } \\
(\text { wt } \%)\end{array}$} & \multicolumn{2}{|c|}{$\begin{array}{c}\text { volatilizable } \\
\text { inorganic } \\
\text { compounds } \\
\text { (wt \%) }\end{array}$} & \multirow[b]{2}{*}{ residual ash (wt \%) } & \multirow[b]{2}{*}{ total solid yield ( $\mathrm{g} / \mathrm{kg}$ fuel, daf basis) } \\
\hline & & & $\mathrm{KCl}$ & $\mathrm{K}_{2} \mathrm{SO}_{4}$ & & \\
\hline \multicolumn{7}{|c|}{ Filter Samples } \\
\hline wood, $T=1000{ }^{\circ} \mathrm{C}, \mathrm{H}_{2} \mathrm{O} / \mathrm{C}=0.5$ & 1.0 & 96.3 & 0.0 & 1.0 & 1.8 & 9.6 \\
\hline wood, $T=1400{ }^{\circ} \mathrm{C}, \mathrm{H}_{2} \mathrm{O} / \mathrm{C}=0.5$ & 0.9 & 92.6 & 0.0 & 4.2 & 2.3 & 12.2 \\
\hline straw, $T=1000{ }^{\circ} \mathrm{C}, \mathrm{H}_{2} \mathrm{O} / \mathrm{C}=0.5$ & 1.6 & 67.1 & 14.1 & 1.0 & 16.1 & 13.2 \\
\hline straw, $T=1400{ }^{\circ} \mathrm{C}, \mathrm{H}_{2} \mathrm{O} / \mathrm{C}=0.0$ & 2.7 & 43.7 & 21.3 & 6.0 & 26.3 & 12.3 \\
\hline straw, $T=1400{ }^{\circ} \mathrm{C}, \mathrm{H}_{2} \mathrm{O} / \mathrm{C}=0.5$ & 2.2 & 11.1 & 38.2 & 9.2 & 39.3 & 5.3 \\
\hline straw, $T=1400{ }^{\circ} \mathrm{C}, \mathrm{H}_{2} \mathrm{O} / \mathrm{C}=1.0$ & 1.6 & 5.9 & 40.7 & 9.9 & 41.9 & 5.2 \\
\hline dried lignin, $T=1400{ }^{\circ} \mathrm{C}, \mathrm{H}_{2} \mathrm{O} / \mathrm{C}=0.5$ & 0.8 & 44.9 & 0.9 & 0.6 & 52.9 & 19.2 \\
\hline \multicolumn{7}{|c|}{ Cyclone Samples } \\
\hline wood, $T=1000{ }^{\circ} \mathrm{C}, \mathrm{H}_{2} \mathrm{O} / \mathrm{C}=0.5$ & 4.4 & 60.9 & 0.5 & 2.4 & 31.8 & 1.4 \\
\hline straw, $T=1000{ }^{\circ} \mathrm{C}, \mathrm{H}_{2} \mathrm{O} / \mathrm{C}=0.5$ & 5.2 & 42.6 & 2.3 & 1.2 & 48.7 & 1.4 \\
\hline
\end{tabular}

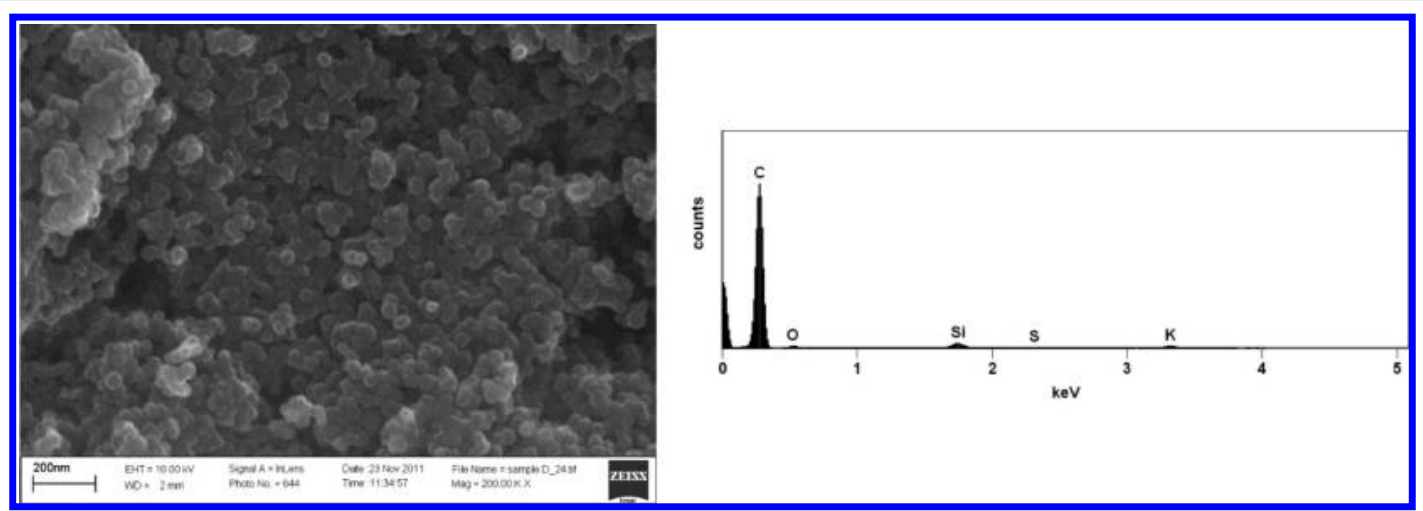

Figure 4. SEM image with EDS spectrum of the wood filter sample obtained from entrained flow gasification (operating parameters: $T=1400{ }^{\circ} \mathrm{C}$; $\left.\mathrm{H}_{2} \mathrm{O} / \mathrm{C}=0.5 ; \lambda=0.3 ; \mathrm{O}_{2}=21 \%\right)$.

parameters (reactor temperature $=1400{ }^{\circ} \mathrm{C}$; excess air ratio $=$ 0.3 ; and oxygen concentration $=21 \%$ ) is listed in Table 2 , and the corresponding weight loss curves (TG) are shown in the Supporting Information. Without steam addition $\left(\mathrm{H}_{2} \mathrm{O} / \mathrm{C}=\right.$ $0.0)$, the soot content (43.7 wt \%) in the filter sample is relatively high, while with steam addition the soot content quickly decreases (11.1 wt \% at $\mathrm{H}_{2} \mathrm{O} / \mathrm{C}=0.5$ and 5.9 wt $\%$ at $\mathrm{H}_{2} \mathrm{O} / \mathrm{C}=1.0$ ) owing to the soot-steam gasification reaction. Additionally, when an almost fixed amount of syngas was drawn to the solid sampling system in the gasification experiments, the amount of collected filter sample also decreased with increasing steam/carbon molar ratio. These observations further confirm that steam addition is helpful to reduce soot emission. As a consequence of the lower soot content, the $\mathrm{KCl}$ and $\mathrm{K}_{2} \mathrm{SO}_{4}$ contents increased from 21.3 to $40.7 \mathrm{wt} \%$ and from 6.0 to 9.9 wt \%, respectively, with the steam/carbon molar ratio increasing from 0.0 to 1.0. The total amounts of $\mathrm{KCl}$ and $\mathrm{K}_{2} \mathrm{SO}_{4}$ collected in the filter sample, however, were nearly unchanged.

During wood and straw entrained flow gasification, char particles were found in the cyclone only at $1000{ }^{\circ} \mathrm{C}$. The composition of cyclone samples obtained from entrained flow gasification of wood and straw respectively with fixed operating parameters (reactor temperature $=1000{ }^{\circ} \mathrm{C}$; excesssteam/ carbon ratio $=0.5$; excess air ratio $=0.3$; and oxygen concentration $=21 \%$ ) is listed in Table 2 , and the corresponding weight loss curves (TG) are shown in the Supporting Information. The straw char has higher ash content than wood char because of the higher ash content in straw. Besides, compared with soot, we found that the ash content in char was higher.

Four filter samples, one obtained from wood gasification and the other three obtained from straw gasification, which were already analyzed by STA and listed in Table 2, were further investigated by SEM with EDS analysis. Figure 4 shows the SEM image with EDS spectrum of the filter sample obtained from wood gasification (reactor temperature $=1400{ }^{\circ} \mathrm{C}$; steam $/$ carbon ratio $=0.5$; excess air ratio $=0.3$; and oxygen concentration $=21 \%$ ). In the previous STA analysis, we found soot (92.6 wt \%) is the major component in the filter sample. In the SEM image, it can be observed that the single soot particles are nanosized carbon spheres $(<100 \mathrm{~nm})$ that are agglomerated together to form clusters and chains of spheres. This is agreement with the structure of soot reported in the literature, ${ }^{27}$ where it was also shown that there was no visual difference observed between soot produced at 1200 and 1400 ${ }^{\circ} \mathrm{C}$ during wood (beech sawdust) pyrolysis in a drop tube furnace. The wood filter sample is almost homogeneous. The EDS spectrum of this sample reveals that it is very rich in carbon because of the very high soot content, and includes traces of oxygen, silica, sulfur, and potassium due to low fractions of $\mathrm{K}_{2} \mathrm{SO}_{4}$ and $\mathrm{SiO}_{2}$ being present. The obtained results by SEM with EDS are in qualitative agreement with the results obtained by STA.

Figure 5 shows the SEM images with EDS spectra of the three filter samples obtained from straw gasification (reactor 


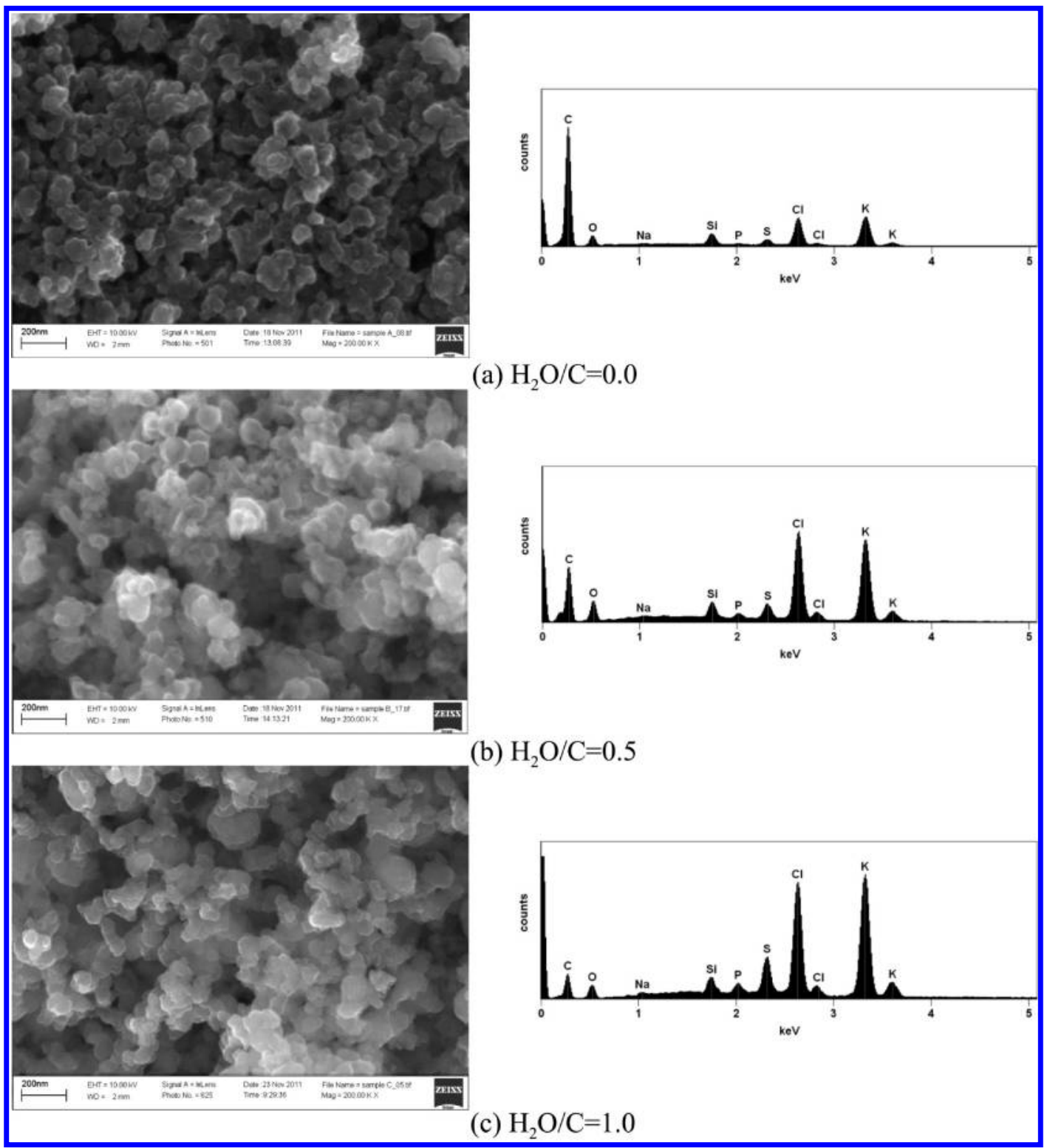

Figure 5. SEM images with EDS spectra of the straw filter samples obtained from entrained flow gasification (operating parameters: $T=1400{ }^{\circ} \mathrm{C}$; $\mathrm{H}_{2} \mathrm{O} / \mathrm{C}=0.0,0.5$, and $\left.1.0 ; \lambda=0.3 ; \mathrm{O}_{2}=21 \%\right)$.

temperature $=1400{ }^{\circ} \mathrm{C}$; steam $/$ carbon ratio $=0.0,0.5$, and 1.0 ; excess air ratio $=0.3$; and oxygen concentration $=21 \%)$. The straw filter samples are almost homogeneous. In Figure 5a, without steam addition $\left(\mathrm{H}_{2} \mathrm{O} / \mathrm{C}=0.0\right)$, the straw filter sample looks similar to the wood filter sample, shown in Figure 4, because of the relatively high soot content (43.7 wt \%) in the straw filter sample. However, compared with the wood filter sample, the particle size of the straw filter sample looks larger and the shapes of the particles are irregular instead of spherical. This is probably because of the larger amount of $\mathrm{KCl}$ and $\mathrm{K}_{2} \mathrm{SO}_{4}$ present, which adsorbs on the surface of the soot particles. In its EDS spectrum, it can be found that the filter sample is mainly composed of carbon and also includes potassium and chlorine and minor fractions of oxygen, silica, and sulfur. In Figure $5 b$, with steam addition $\left(\mathrm{H}_{2} \mathrm{O} / \mathrm{C}=0.5\right)$, the particle size further increases $(>100 \mathrm{~nm})$ and the irregular particle shape indicates that crystalline materials are present in agreement with the high contents of $\mathrm{KCl}$ and $\mathrm{K}_{2} \mathrm{SO}_{4}$. The EDS spectrum of this filter sample shows that carbon, potassium, and chlorine are present in significant amounts. In Figure 5c, at $\mathrm{H}_{2} \mathrm{O} / \mathrm{C}=1.0$, the particles entirely lost the spherical shape and the boundary of different particles vanished due to their conjunction, probably because of the low soot content and high $\mathrm{KCl}$ and $\mathrm{K}_{2} \mathrm{SO}_{4}$ contents in the filter sample. In the corresponding EDS spectrum, it can be observed that the filter sample is rich in potassium and chlorine and contains additionally carbon, oxygen, sodium, silica, phosphor, and sulfur. The EDS results of the three straw filter samples are all in accordance with their STA results.

The SEM images of the parent wood particle used as fuel and the derived char sample collected by the cyclone during wood entrained flow gasification (reactor temperature $=1000{ }^{\circ} \mathrm{C}$; steam $/$ carbon ratio $=0.5$; excess air ratio $=0.3$; and oxygen concentration $=21 \%$ ) are shown in Figure 6 . Both the parent wood particles and the derived char particles have a layered structure with a loose and porous texture. Furthermore, the size and shape of the derived char particle are similar to that of the parent wood particle; thus, complete melting of the char 


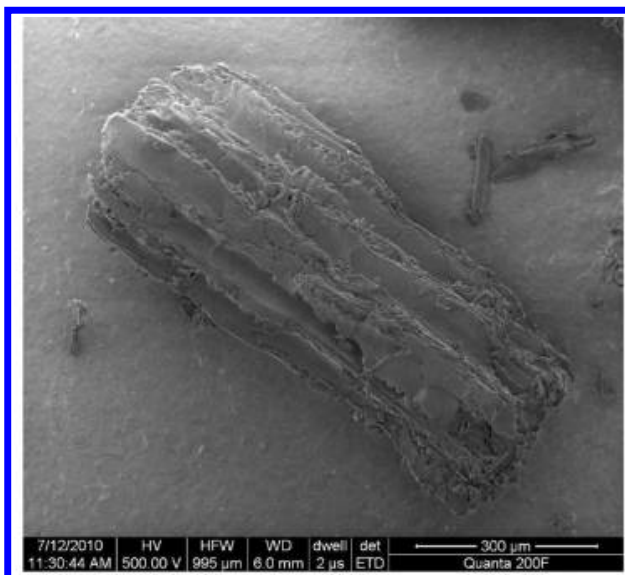

(a) image of the parent wood particle

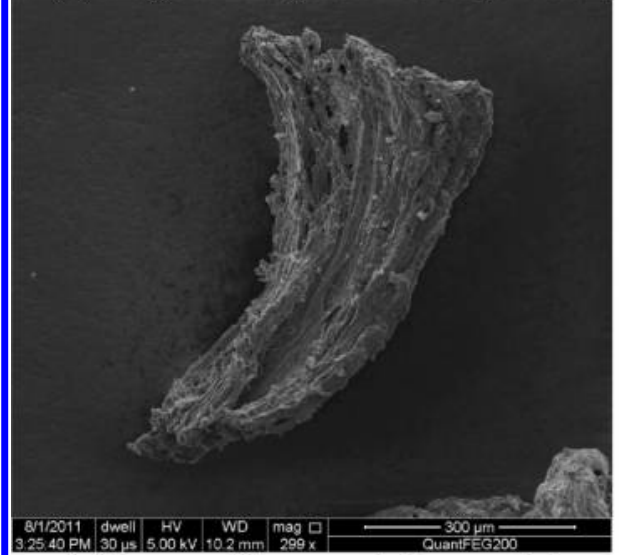

(c) image of the wood char particle

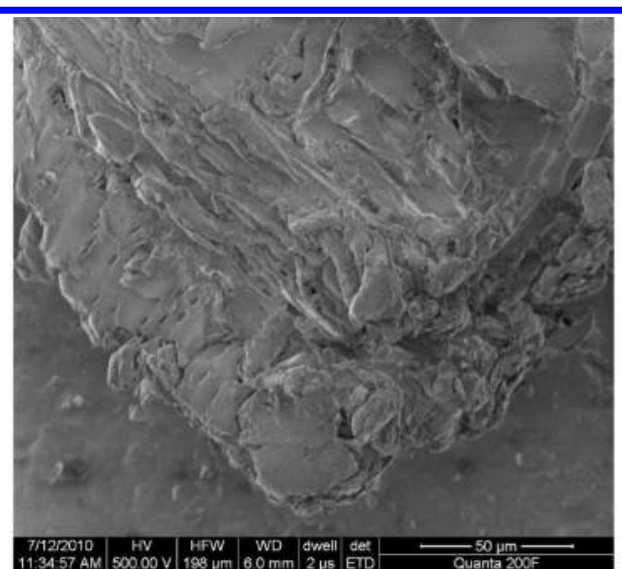

(b) enlarged image of the parent wood particle

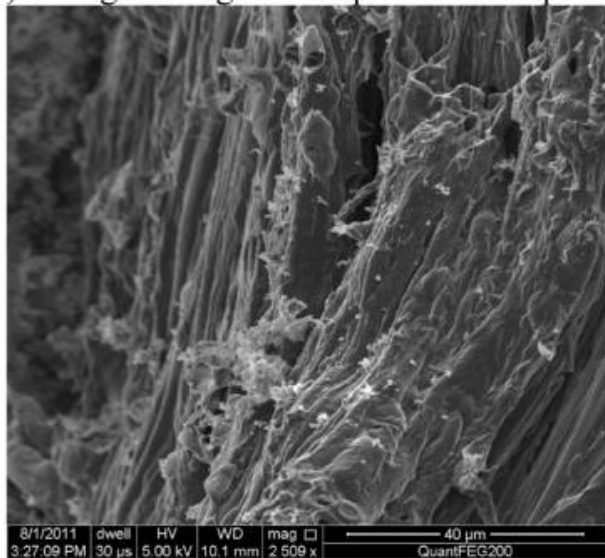

(d) enlarged image of the wood char particle

Figure 6. SEM image of the parent wood particle and the derived wood char particle (cyclone sample) obtained from entrained flow gasification (operating parameters: $\mathrm{T}=1000{ }^{\circ} \mathrm{C} ; \mathrm{H}_{2} \mathrm{O} / \mathrm{C}=0.5 ; \lambda=0.3 ; \mathrm{O}_{2}=21 \%$ ).

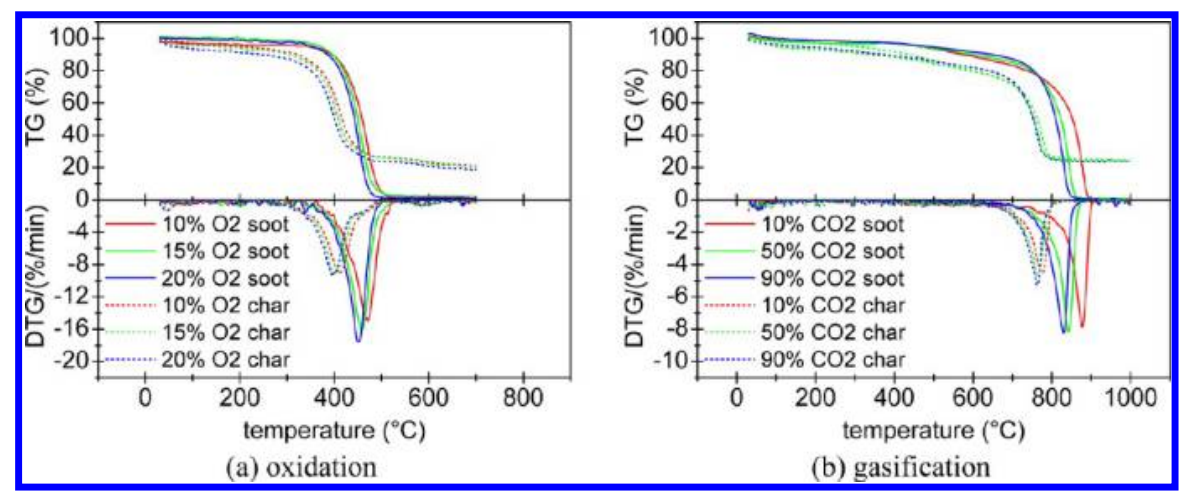

Figure 7. TG and DTG curves for the oxidation and gasification $\left(\mathrm{O}_{2}\right.$ or $\mathrm{CO}_{2}$ in $\left.\mathrm{N}_{2}\right)$ of the wood soot (obtained from entrained flow gasification at $1400{ }^{\circ} \mathrm{C}$ ) and the wood char (obtained from entrained flow gasification at $1000{ }^{\circ} \mathrm{C}$ ).

particles does not take place. ${ }^{28,29}$ However, in comparison to the wood particle, the surface of the derived char particle looks smoother, which probably indicates partial melting. ${ }^{29,30}$

Kinetics of Char and Soot Particles. The kinetics of oxidation and $\mathrm{CO}_{2}$ gasification of the soot $\left(T=1400{ }^{\circ} \mathrm{C}\right)$ and char $\left(T=1000{ }^{\circ} \mathrm{C}\right)$ samples produced during wood entrained flow gasification were determined. The gasification with $\mathrm{H}_{2} \mathrm{O}$ was not investigated since the STA does not allow addition of steam, although this gasification agent would have been most relevant. However, it is generally accepted that the reactivity with respect to $\mathrm{H}_{2} \mathrm{O}$ gasification is approximately 2-5 times higher than gasification with $\mathrm{CO}_{2}$, and so, the results obtained here for $\mathrm{CO}_{2}$ may to some extent be generalized. ${ }^{31,32}$ The weight loss curves (TG) and the corresponding differential weight loss curves (DTG) for the oxidation and gasification of the soot and char in different $\mathrm{O}_{2}$ and $\mathrm{CO}_{2}$ concentrations are shown in Figure 7. As expected, the TG and DTG curves are shifted to lower temperatures with increasing $\mathrm{O}_{2}$ or $\mathrm{CO}_{2}$ concentration. The soot and char are oxidized approximately between 300 and $600{ }^{\circ} \mathrm{C}$ in different $\mathrm{O}_{2}$ concentrations, while they are gasified at higher temperatures in different $\mathrm{CO}_{2}$ concentrations, approximately between $600-1000{ }^{\circ} \mathrm{C}$. The temperature at the maximum rate of weight loss is commonly used to characterize reactivity. ${ }^{33}$ Figure 7 a shows that the 
Table 3. Kinetic Parameters of the Wood Char (Obtained from Entrained Flow Gasification at $1000{ }^{\circ} \mathrm{C}$ ) and the Wood Soot (Obtained from Entrained Flow Gasification at 1400, 1300, 1100, and $1000{ }^{\circ} \mathrm{C}$ ) Oxidation and Gasification

\begin{tabular}{|c|c|c|c|c|c|}
\hline samples & char & soot & soot & soot & soot \\
\hline sample temp. & $1000{ }^{\circ} \mathrm{C}$ & $1400{ }^{\circ} \mathrm{C}$ & $1300{ }^{\circ} \mathrm{C}$ & $1100{ }^{\circ} \mathrm{C}$ & $1000{ }^{\circ} \mathrm{C}$ \\
\hline oxidation in STA & 10,15 , and $20 \mathrm{vol} \%$ & 10,15 , and 20 vol $\%$ & 10 vol \% & 10 vol \% & 10 vol \% \\
\hline & $\mathrm{O}_{2}$ in $\mathrm{N}_{2}$ & $\mathrm{O}_{2}$ in $\mathrm{N}_{2}$ & $\mathrm{O}_{2}$ in $\mathrm{N}_{2}$ & $\mathrm{O}_{2}$ in $\mathrm{N}_{2}$ & $\mathrm{O}_{2}$ in $\mathrm{N}_{2}$ \\
\hline$n$ & 1.0 & 1.0 & 1.0 & 1.0 & 1.0 \\
\hline$m$ & 0.71 & 0.99 & 0.99 & 0.99 & 0.99 \\
\hline$A_{0}\left(\mathrm{~s}^{-1} \mathrm{MPa}^{-m}\right)$ & $1.43 \times 10^{8}$ & $1.43 \times 10^{10}$ & $1.59 \times 10^{10}$ & $7.19 \times 10^{19}$ & $8.59 \times 10^{19}$ \\
\hline$E(\mathrm{~kJ} / \mathrm{mol})$ & 119 & 148 & 153 & 315 & 325 \\
\hline gasification in STA & 10,50 , and $90 \mathrm{vol} \%$ & 10,50 , and 90 vol $\%$ & 10 vol $\%$ & 10 vol \% & 10 vol \% \\
\hline & $\mathrm{CO}_{2}$ in $\mathrm{N}_{2}$ & $\mathrm{CO}_{2}$ in $\mathrm{N}_{2}$ & $\mathrm{CO}_{2}$ in $\mathrm{N}_{2}$ & $\mathrm{CO}_{2}$ in $\mathrm{N}_{2}$ & $\mathrm{CO}_{2}$ in $\mathrm{N}_{2}$ \\
\hline$n$ & 0.5 & 0.5 & 0.5 & 0.5 & 0.5 \\
\hline$m$ & 0.12 & 0.54 & 0.54 & 0.54 & 0.54 \\
\hline$A_{0}\left(\mathrm{~s}^{-1} \mathrm{MPa}^{-m}\right)$ & $1.25 \times 10^{8}$ & $3.61 \times 10^{9}$ & $4.42 \times 10^{9}$ & $5.53 \times 10^{9}$ & $1.16 \times 10^{10}$ \\
\hline$E(\mathrm{~kJ} / \mathrm{mol})$ & 213 & 247 & 261 & 279 & 292 \\
\hline
\end{tabular}

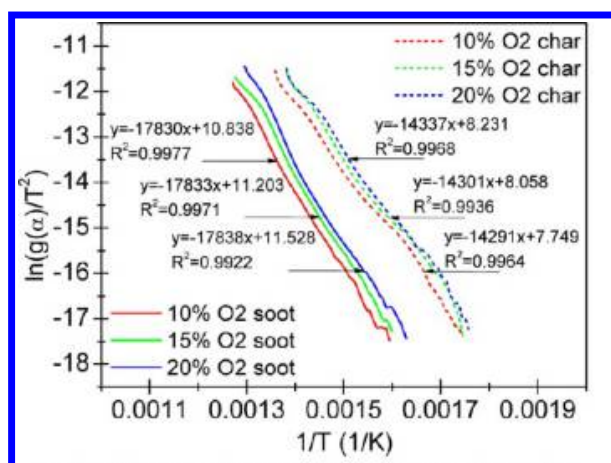

(a) oxidation: linear fitting for equation (6)

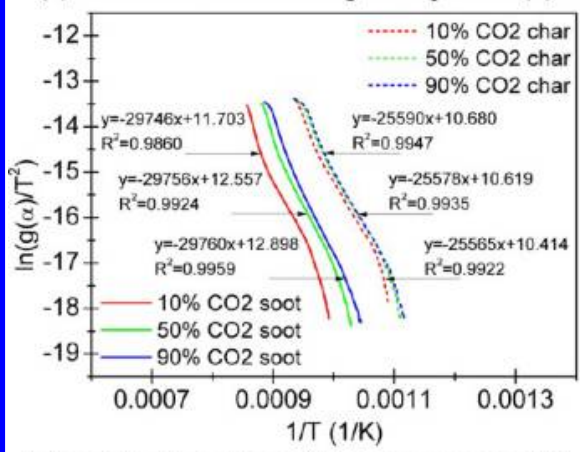

(c) gasification: linear fitting for equation (6)

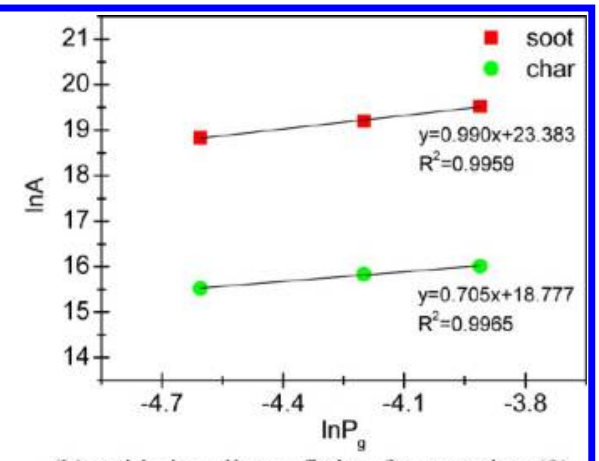

(b) oxidation: linear fitting for equation (9)

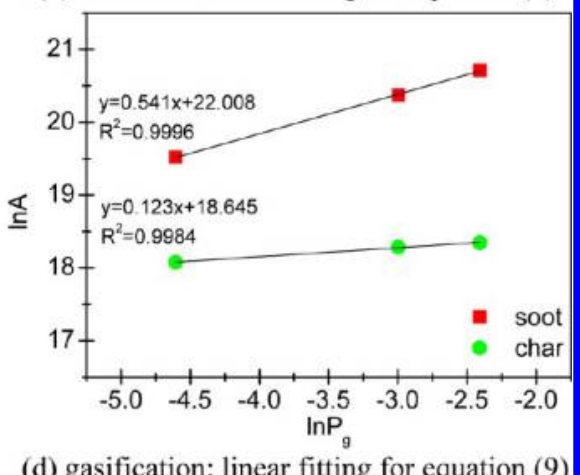

Figure 8. Linearized $n$th order reaction model for oxidation and gasification of the wood soot (obtained from entrained flow gasification at $1400{ }^{\circ} \mathrm{C}$ ) and the wood char (obtained from entrained flow gasification at $1000{ }^{\circ} \mathrm{C}$ ): $n=1.0$ for oxidation and $n=0.5$ for gasification.

oxidation reaction for char reaches the maximum rate at $400-$ $410{ }^{\circ} \mathrm{C}$, which is approximately $50-60{ }^{\circ} \mathrm{C}$ lower than for soot. As shown in Figure $7 \mathrm{~b}$, the char gasification reaches the maximum rate at $760-780{ }^{\circ} \mathrm{C}$, while the soot gasification reaches the maximum rate at $820-880{ }^{\circ} \mathrm{C}$. Thus, the char is more reactive than soot during both oxidation and gasification.

The kinetic parameters of the soot and char oxidation and gasification, which were derived by the integral method described in section 2.4, are listed in Table 3. The plots of eqs 6 and 9 for char and soot oxidation and gasification are shown in Figure 8. We found that good linear fittings can be obtained for $n=1.0$ for both soot and char oxidation in different $\mathrm{O}_{2}$ concentrations and for $n=0.5$ for both soot and char gasification in different $\mathrm{CO}_{2}$ concentrations. It can be seen that the activation energy is higher for soot conversion than for char conversion. This is probably because the char has a less ordered structure of carbon compared to the more graphitic soot.

The obtained kinetic parameters, listed in Table 3, were employed in the $n$th order reaction model, shown in eq 3 , to simulate the soot and char conversion under oxidation and gasification conditions. We found that the $n$th order reaction model can describe the experimental results well with respect to both soot and char oxidation and gasification. The oxidation rate of the char was about 5-10 times faster than that of the soot in the studied temperature range, while the gasification rate of the char was about 5-20 times faster than that of the soot. The results show that an important reason for not converting all soot in the available residence time in the entrained flow reactor is the low reactivity of soot.

As we mentioned, in the experiments of wood gasification at $1000-1400{ }^{\circ} \mathrm{C}$, unconverted char was found only at $1000{ }^{\circ} \mathrm{C}$, while soot was always observed in the whole studied 
temperature range. Thus, the reactivity of the five wood soot samples obtained at $1000-1400{ }^{\circ} \mathrm{C}$ and the wood char sample produced at $1000{ }^{\circ} \mathrm{C}$ are compared. The weight loss curves for the oxidation ( $10 \mathrm{vol} \% \mathrm{O}_{2}$ in $\mathrm{N}_{2}$ ) and gasification ( $10 \mathrm{vol} \%$ $\mathrm{CO}_{2}$ in $\mathrm{N}_{2}$ ) of these samples are shown in Figure 9, while the

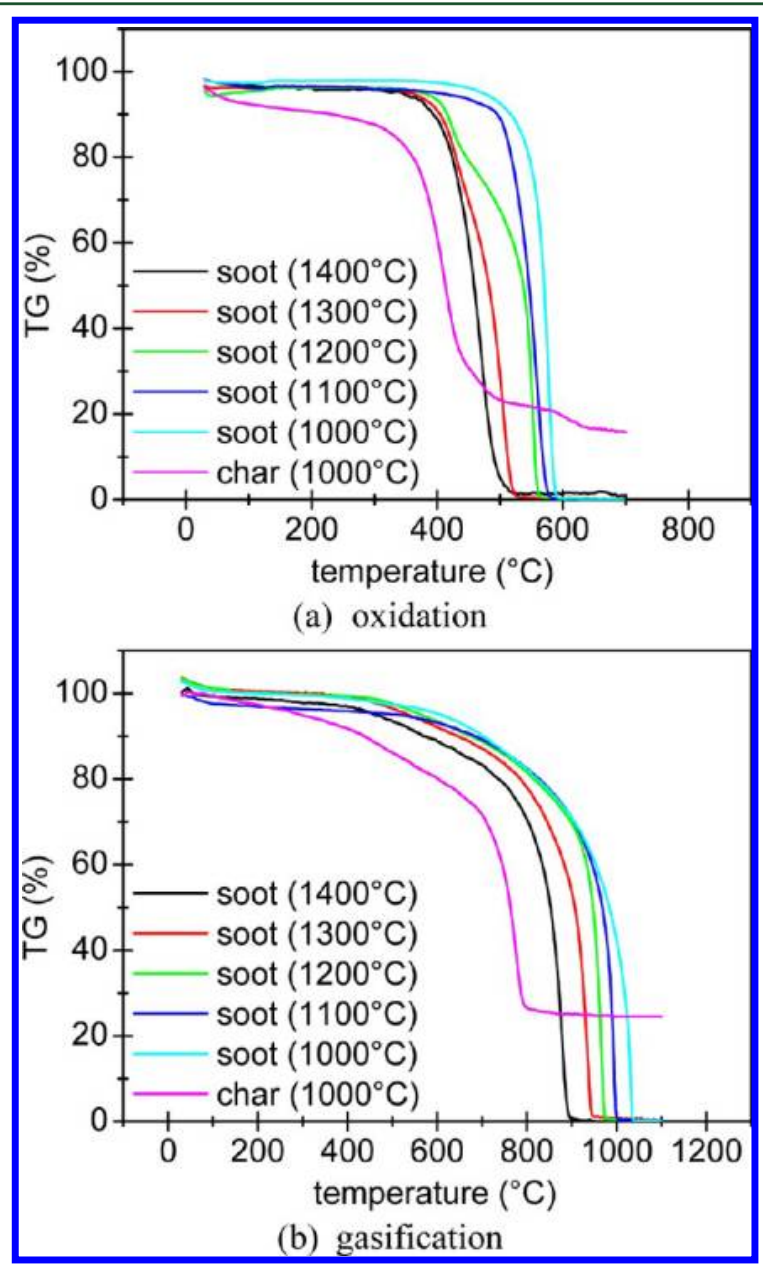

Figure 9. Weight loss curves for the oxidation and gasification (10 vol $\% \mathrm{O}_{2}$ or $\mathrm{CO}_{2}$ in $\mathrm{N}_{2}$ ) of the wood soot obtained from entrained flow gasification at $1000-1400{ }^{\circ} \mathrm{C}$ and the wood char obtained from entrained flow gasification at $1000{ }^{\circ} \mathrm{C}$.

derived kinetic parameters ( $n$ and $m$ are fixed) are also shown in Table 3. The weight loss curve of the wood soot produced at $1200{ }^{\circ} \mathrm{C}$ looks different from the other curves; thus, the employed one-step $n$th order reaction model could not describe its conversion well. During both oxidation and gasification, the conversion of the soot produced at a higher temperature takes place at a lower temperature in the STA measurements. This reveals that both the oxidation reactivity and gasification reactivity of soot increase when the soot is produced at a higher temperature. This is surprising since the reactivity of solid carbonaceous fuel normally decreases with increasing pyrolysis temperature. ${ }^{30,34}$ However, as listed in Table 2, the potassium content is higher in the soot produced at a higher temperature. Therefore, the higher reactivity of soot produced at a higher temperature may be related to the presence of potassium, perhaps as intercalated species in the carbon, which is known to catalyze gasification reactions. ${ }^{35,36}$ Further experiments would be required to verify this proposal in detail. Moreover, it also can be observed that the char produced at $1000{ }^{\circ} \mathrm{C}$ is more reactive than the soot produced at the same temperature as well as the soot produced at higher temperatures.

\section{CONCLUSIONS}

Biomass (wood, straw, and dried lignin) gasification was carried out in a lab scale atmospheric pressure entrained flow reactor. In the experiments, the solid products in the syngas were collected successively by a cyclone and a metal filter. In the cyclone, solid particles were collected only in the gasification experiments conducted at $1000{ }^{\circ} \mathrm{C}$, while solid particles were captured in the metal filter in all the gasification experiments conducted at $1000-1400{ }^{\circ} \mathrm{C}$. The obtained solid samples were analyzed by STA to determine the composition (moisture, organic matters, volatilizable inorganic compound, and residual ash) and by SEM with EDS to obtain the size, morphology, and elemental composition. Furthermore, the reactivity and kinetics of the soot and char produced in the wood gasification experiments were assessed by STA.

During wood gasification, the major part of the collected solids on the filter is soot. The SEM image with the EDS spectrum of the wood filter sample obtained at $1400{ }^{\circ} \mathrm{C}$ shows that the soot particles appear as agglomerated nanosize carbon spheres $(<100 \mathrm{~nm})$ that are rich in carbon. Under the same operating condition $\left(T=1400{ }^{\circ} \mathrm{C}, \mathrm{H}_{2} \mathrm{O} / \mathrm{C}=0.5\right)$, in comparison to wood gasification, the filter sample obtained from straw gasification has a low soot content and high $\mathrm{KCl}$ and $\mathrm{K}_{2} \mathrm{SO}_{4}$ contents. During straw gasification, increasing the steam/carbon molar ratio from 0.0 to 1.0 leads to decreasing soot content in the solids and thereby an increasing $\mathrm{KCl}$ and $\mathrm{K}_{2} \mathrm{SO}_{4}$ content. The SEM images show that increasing the steam/carbon molar ratio from 0.0 to 1.0 leads to changes in the shapes of the particles from spherical to irregular crystals and their size increasing from below $100 \mathrm{~nm}$ to above $100 \mathrm{~nm}$. This is probably caused by $\mathrm{KCl}$ and $\mathrm{K}_{2} \mathrm{SO}_{4}$ deposited on the surface of soot particles. Their EDS spectra show that with steam addition, the carbon peak obviously decreases while the potassium and chlorine peaks notably increase. The filter sample obtained from the dried lignin gasification experiment mainly consisted of soot and nonvolatilizable inorganic matter, since the dried lignin ash is rich in silica and calcium. The SEM images of the parent wood particle and the derived char samples show that both of them have a layered structure with a loose and porous texture. Their similarity indicates that complete melting of char did not take place in the conducted entrained flow gasification experiment $\left(T=1000{ }^{\circ} \mathrm{C}\right)$.

In the study on the kinetics and reactivity of the soot and char, we found that the char is more reactive than soot for both oxidation and gasification, probably due to a less ordered structure of carbon in the char compared to the soot. For both the soot and char, the reaction order with respect to the solid phase is found to be 1.0 during oxidation and 0.5 during gasification. The activation energy of the soot conversion is higher than that of the char conversion. This difference in reactivity partly explains why char is generally fully converted in the conducted entrained flow gasification experiments while soot is not. Moreover, the soot produced at a higher temperature is more reactive than the soot produced at a lower temperature, and the char produced at $1000{ }^{\circ} \mathrm{C}$ is more reactive than the soot produced at the same temperature as well as the soot produced at higher temperatures. 


\section{ASSOCIATED CONTENT}

\section{S Supporting Information}

Weight loss curves (TG) of solid samples obtained from the entrained flow gasification of biomass. This material is available free of charge via the Internet at http://pubs.acs.org.

\section{AUTHOR INFORMATION}

\section{Corresponding Author}

*Tel: +45 452528 41. Fax: +45 458822 58. E-mail: aj@kt. dtu.dk.

Notes

The authors declare no competing financial interest.

\section{ACKNOWLEDGMENTS}

This work is part of the Combustion and Harmful Emission Control (CHEC) Research Centre at the Department of Chemical and Biochemical Engineering, Technical University of Denmark. The Danish Research Council for Technology and Production under project 09-064201/FTP and the Danish Energy Agency are acknowledged for sponsoring the project.

\section{REFERENCES}

(1) Balat, M.; Balat, M.; Kırtay, E.; Balat, H. Enerov Convers. Manage. 2009, 12, 3158-3168.

(2) Higman, C.; Van der Burgt, M. Gasification processes. In

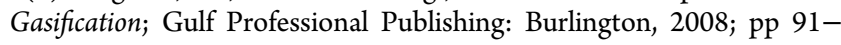
93.

(3) Syngas Production from Coal, Technology Brief S01; IEA ETSAP: Paris, France, May 2010. Available online: http://www.iea-etsap.org/ web/E-TechDS/PDF/S01-Coal\%20gasification-GS-gct.pdf.

(4) Crnomarkovic, N.; Repic, B.; Mladenovic, R.; Neskovic, O.; Veljkovic, M. Fuel 2007, 1-2, 194-202.

(5) Van der Drift, A.; Boerrigter, H.; Coda, B.; Cieplik, M.; Hemmes, K.; van Ree, R.; Veringa, H. Entrained Flow Gasification of Biomass: Ash Behavior, Feeding Issues, and System Analyses; ECN: Petten, The Netherlands, 2004.

(6) Kajitani, S.; Suzuki, N.; Ashizawa, M.; Hara, S. Fuel 2006, 2, 163169.

(7) Choi, Y.; Li, X.; Park, T.; Kim, J.; Lee, J. Fuel 2001, 15, 21932201.

(8) Kristiansen, A. Understanding Coal Gasification; IEA Coal Research: Paris, France, 1996.

(9) Henrich, E.; Weirich, F. Environ. Eng. Sci. 2004, 1, 53-64.

(10) Johansson, T. B.; Kelly, H.; Reddy, A. K. N.; Williams, R.; Drennen, T. E. Renewable Energy: Sources for Fuels and Electricity; Island Press: Washington, DC, 1992; pp 593-651.

(11) Milne, T. A.; Abatzoglou, N.; Evans, R. J. Biomass Gasifier Tars: Their Nature, Formation, and Conversion; National Renewable Energy Laboratory: Golden, CO, 1998.

(12) El-Rub, Z. A.; Bramer, E.; Brem, G. Tar removal in an Entrained Flow Cracker (EFC) with application to biomass gasification. Pyrolysis and Gasification of Biomass and Waste: Proceedings of an Expert Meeting, Strasbourg, France, Sept. 30-Oct. 1, 2002; CLP Press: United Kingdom, 2003; pp 337-346.

(13) Kirubakaran, V.; Sivaramakrishnan, V.; Nalini, R.; Sekar, T.; Premalatha, M.; Subramanian, P. Renewable Sustainable Energy Rev. 2009, 1, 179-186.

(14) Bridgwater, A. Fuel 1995, 5, 631-653.

(15) Gao, C.; Vejahati, F.; Katalambula, H.; Gupta, R. Energy Fuels 2009, 1, 232-240.

(16) Qin, K.; Jensen, P. A.; Lin, W.; Jensen, A. D. Energy Fuels 2012, 5992-6002.

(17) Henrich, E.; Burkle, S.; Meza-Renken, Z.; Rumpel, S. J. Anal. Appl. Pyrolysis 1999, 1-2, 221-241.

(18) Qin, K.; Lin, W.; Jensen, P. A.; Jensen, A. D. Fuel 2012, 589600 .
(19) Coats, A.; Redfern, J. Nature 1964, 68-69.

(20) Popescu, C.; Segal, E. Int. I. Chem. Kinet. 1998, 5, 313-327.

(21) Arvelakis, S.; Jensen, P. A.; Dam-Johansen, K. Energy Fuels 2004, 4, 1066-1076.

(22) Hansen, L. A.; Frandsen, F. J.; Dam-Johansen, K.; Sørensen, H. S. Thermochim. Acta 1999, 1-2, 105-117.

(23) Hindiyarti, L.; Frandsen, F.; Livbjerg, H.; Glarborg, P.; Marshall, P. Fuel 2008, 8, 1591-1600.

(24) Jensen, J. R.; Nielsen, L. B.; Schultz-Møller, C.; Wedel, S.; Livbjerg, H. Aerosol. Sci. Technol. 2000, 6, 490-509.

(25) Christensen, K. A.; Livbjerg, H. Aerosol. Sci. Technol. 2000, 6, 470-489.

(26) Glarborg, P.; Marshall, P. Combust. Flame 2005, 1, 22-39.

(27) Septien, S.; Valin, S.; Dupont, C.; Peyrot, M.; Salvador, S. Fuel 2012, 97, 202-210.

(28) Zhang, Y.; Kajitani, S.; Ashizawa, M.; Miura, K. Energy Fuels 2006, 6, 2705-2712.

(29) Dall'Ora, M.; Jensen, P. A.; Jensen, A. D. Energy Fuels 2008, 5, 2955-2962.

(30) Zolin, A.; Jensen, A.; Jensen, P. A.; Frandsen, F.; Dam-Johansen, K. Energy Fuels 2001, 5, 1110-1122.

(31) Watanabe, H.; Otaka, M. Fuel 2006, 12-13, 1935-1943.

(32) Laurendeau, N. M. Prog. Energy Combust. Sci. 1978, 221-270.

(33) Cozzani, V. Ind. Eng. Chem. Res. 2000, 4, 864-872.

(34) Zolin, A.; Jensen, A. D.; Jensen, P. A.; Dam-Johansen, K. $\underline{\text { Fuel }}$ 2002, 8, 1065-1075.

(35) Wen, W. Y. Catal. Rev.-Sci. Eng. 1980, 1, 1-28.

(36) Wigmans, T.; Hoogland, A.; Tromp, P.; Moulijn, J. A. Carbon $1983,1,13-22$. 